\title{
PROJEKTYZACJA JAKO PRZEDMIOT BADAŃ W RAMACH STUDIÓW NAD PROJEKTAMI
}

https://doi.org/10.33141/po.2019.08.05

Beata Jałocha
Przegląd Organizacji, Nr 8 (955), 2019, ss. 34-41 www.przegladorganizacji.pl CTowarzystwo Naukowe Organizacji i Kierownictwa (TNOiK)

\section{Wprowadzenie}

$\mathbf{Z}$ arządzanie projektami, zarówno jako praktyka organizacyjna, jak i obszar refleksji naukowej, jest przedmiotem wzmożonego zainteresowania praktyków oraz badaczy od co najmniej kilkudziesięciu lat. W świecie organizacji projekty stały się jedną z kluczowych form realizacji zadań na poziomach operacyjnym oraz strategicznym. W biznesie, sektorze publicznym i pozarządowym kilkadziesiąt lat doświadczeń zaowocowało usprawnieniem procedur i stworzeniem szeregu metodyk projektowych podnoszących efektywność realizowanych przedsięwzięć. W świecie nauki studia nad projektami (project studies) stanowią odrębny obszar badań (Geraldi, Söderlund, 2018; Trocki, 2019) i coraz rzadziej kwestionowane są ich zasadność, rzetelność i teoriotwórczość.

Tradycyjne badania nad projektami, prowadzone od lat 40. XX wieku, dotyczyły zazwyczaj procesu zarządzania pojedynczym projektem w jednej lokalizacji, realizowanego przez jedną, dwie lub większą liczbę organizacji (Evaristo, van Fenema, 1999, s. 275). Podejście to nie pozwalało jednak na zrozumienie złożoności procesów projektowych i nadążanie za szybko zmieniającym się światem praktyki. Koncepcje i techniki, które zrodziły się w ramach nurtu tzw. klasycznego zarządzania projektami, okazały się niejednokrotnie nieprzystające do potrzeb współczesnych organizacji (Morris, 1994, s. viii). Obecnie badacze przestali skupiać się jedynie na pojedynczych projektach, przenosząc poziom analizy na otoczenie mikro- i makroekonomiczne, w jakich są one realizowane (Geraldi, Söderlund, 2018, s. 56). O projektach zaczęto myśleć więc szerzej, odchodząc od podejścia, które definiowało „projekt jako narzędzie” do idei „projektu, jako organizacji tymczasowej" (Packendorff, 1995, s. 319; Svejvig, Andersen, 2015, s. 278). Zarządzanie projektami rozumiane jest obecnie jako holistyczna dyscyplina, pozwalająca na osiąganie organizacyjnej wydajności, skuteczności i innowacyjności, a nie jedynie zestaw praktyk i narzędzi (Svejvig, Andersen, 2015; Jugdev i in., 2001), posiadająca odrębny przedmiot badań, własne podstawy teoretyczne i stosująca specyficzne metody badawcze (Trocki, Bukłaha, 2016, s. 9).

Oprócz rozszerzenia przedmiotu badań, ewolucja studiów nad projektami polegała również na wyłonieniu nowych podejść do realizacji procesu badawczego, wychodzących znacząco poza dotychczas wiodący, a jed- nocześnie bardzo ograniczający poznanie zjawiska, nurt funkcjonalistyczny. Eklektyzm metodologiczny, jaki obecnie dominuje $\mathrm{w}$ badaniach nad projektami, pozwolił na rozszerzenie przedmiotu badań o nowe, dotychczas niezbadane obszary. Przyjęcie i uznanie alternatywnych ontologii i epistemologii $\mathrm{w}$ ramach badań nad projektami znacząco wzbogaca tę specjalność naukową (Geraldi, Söderlund, 2018, s. 55).

Jak pokazują badania (Pollack, Adler, 2015, s. 236-248), $\mathrm{w}$ zarządzaniu projektami pojawiają się liczne nowe trendy badawcze, które rozszerzają przedmiot refleksji w ramach tej specjalności naukowej. Badacze zarządzania projektami odchodzą od podejmowania problematyki mocno nakierowanej na rozwiązywanie problemów techniczno-inżynieryjnych, w kierunku badania kontekstu organizacyjno-społecznego projektów. Jednym z zagadnień, jakie wyłoniło się w ramach współczesnych badań nad projektami, jest projektyzacja (projectification). Zjawisko to powiązane jest z powszechnością przyjęcia projektów jako jednej z podstawowych form realizacji działań, nie tylko $\mathrm{w}$ organizacjach, ale również poza nimi. Badania M. Jacobssona i B. Jałochy (2018) wskazują jednoznacznie, że w ciągu ostatnich 25 lat, czyli od momentu publikacji przełomowego tekstu Ch. Midlera (1995), dotyczącego projektyzacji firmy Renault, nastąpił niezwykle intensywny rozwój zainteresowania projektyzacją. Jednocześnie istnieje potrzeba bardziej szczegółowego usystematyzowania wiedzy na temat projektyzacji jako części badań dotyczących projektów.

Celem niniejszego artykułu jest omówienie zagadnienia projektyzacji jako elementu wchodzącego w skład przedmiotu badań studiów nad projektami. W pracy ${ }^{1}$ postawiono następujące pytania badawcze:

PB1: W jaki sposób definiowana jest projektyzacja?

PB2: W odniesieniu do jakich poziomów i w ramach jakich obszarów badane jest zjawisko projektyzacji?

Artykuł ma charakter koncepcyjny, a jego celem jest synteza wiedzy z zakresu projektyzacji na tle teoretycznym studiów nad projektami. Literatura, która posłużyła jako materiał do dokonanej analizy, składa się z artykułów naukowych, w tym opublikowanych w uznanych czasopismach dotyczących zarządzania projektami (PMJ, IJMPB, IJPM), wydawnictwach pokonferencyjnych (np. IRNOP, IPMA Research), oraz monografii naukowych. Obrana metoda miała formę tradycyjnego przeglądu literatury 
(traditional literature review) (Jesson i in., 2011, s. 73). Przegląd opierał się głównie na wyszukiwaniach w bazie Google Scholar, z użyciem słów kluczowych „projectification” oraz "project studies". Wybór Google Scholar jako narzędzia wyszukiwania podyktowany był tym, iż wyszukiwarka ta ma bardzo szeroki zakres indeksowania tekstów naukowych (Amara, Landry, 2012) i jest równie wiarygodna jak inne wyszukiwarki (Gehanno i in., 2013). Pod uwage wzięto wybrane publikacje z lat 1995-2018. Wyszukiwania dokonywano w oparciu o tytuły. Następnie czytano abstrakty i poddawano je ocenie wpisywania się w kryteria doboru literatury (tekst o charakterze naukowym, opublikowany w języku angielskim, dotyczący pojęcia projektyzacji lub studiów nad projektami). Po dokonanej selekcji, w celu uporządkowania pozyskanego materiału literaturowego, 32 pełne teksty, do których dostęp był możliwy, zostały wprowadzone do programu NVivo Pro, a następnie poddane krytycznej analizie w odniesieniu do postawionych pytań badawczych.

Układ artykułu jest następujący. Po wprowadzeniu w problematykę tekstu przedstawioną we wstępie omówiony zostanie rozwój studiów nad projektami jako specjalności naukowej. Na tym tle pokazane zostaną wybrane definicje projektyzacji oraz zaproponowana zostanie rozszerzona typologia poziomów badania projektyzacji. W kolejnej części omówione zostaną główne obszary podejmowania refleksji naukowej nad procesami projektyzacji. Artykuł kończy dyskusja podsumowująca, która nakreśla główne trendy w badaniach nad projektyzacją i wskazuje potencjalne kierunki przyszłych badań.

\section{Studia nad projektami: rozwój specjalności naukowej}

$\mathbf{P}$ arafrazując tezę M. Trockiego (2005, s. 7), który tożsamość nauk o zarządzaniu określa jako świadomość wspólnoty i odrębności środowiska nauk o zarządzaniu w stosunku do innych środowisk naukowych, można stwierdzić, że tożsamość studiów nad projektami polega na wspólnocie i odrębności tej specjalności naukowej wobec innych nurtów w ramach nauk o zarządzaniu. Studia nad projektami zajmują się badaniem problemów i wyzwań związanych $\mathrm{z}$ realizacją prac projektowych, zarówno w sformalizowanych organizacjach, jak i poza nimi. Przedmiotem badania są tu projekty w interakcji z ich środowiskiem wewnętrznym i zewnętrznym, a tożsamość tej specjalności naukowej ciągle ewoluuje i dojrzewa.

Wzrastająca różnorodność w ramach jakiejkolwiek dyscypliny naukowej może być zagrożeniem dla jej spójności, w tym spójności pojęciowej i nadmiernego rozproszenia badań prowadzącego do bałkanizacji nauki. Mówimy wtedy często o tworzeniu tzw. umbrella constructs (Hirsch, Levin, 1999, s. 199), wyłaniających się licznych efemerydalnych konstruktów naukowych, które nie przechodzą próby „naukowości”, a także powstawaniu research microtribes (Alvesson i in., 2017, s. 66), oskorupiających się we własnych mikrospołecznościach grup badawczych. Z drugiej strony - dywersyfikacja może przynieść nowe idee, wyzwania intelektualne, wypełnić sale konferencyjne oraz łamy magazynów naukowych inspirującymi, nietuzinkowymi koncepcjami naukowymi. W przypadku zarządzania projektami mamy zdecydowanie do czynienia z drugim scenariuszem - nauka ta wyłania się i ubogaca w wielości poglądów i inspiracji teoretycznych. Dywersyfikacja obszarów badań nad projektami okazała się szczególnie istotna ze względu na fakt wieloletniej dominacji badań, których przedmiotem był sektor budowlany. Była to sytuacja paradoksalna, bo, jak dowiedli R. Evaristo i P.C. van Fenema (1999), projekty realizowane $\mathrm{w}$ sektorze budowlanym reprezentują jedynie niewielki procent wszystkich projektów realizowanych na świecie. Istniało więc zagrożenie, że wnioskowanie na podstawie badań dotyczących jedynie małego wycinka rzeczywistości projektowej może dawać nieprawidłowe rezultaty w odniesieniu do innych sektorów gospodarki (Crawford i in., 2006, s. 175-184). Wzrost różnorodności zainteresowań badawczych w ramach studiów nad projektami zaobserwować możemy na przykładzie papierka lakmusowego trendów badawczych, jakimi są wiodące magazyny naukowe w tej dyscyplinie. Przykładowo, w International Journal of Project Management, który początkowo publikował głównie wyniki badań dotyczących zarządzania w inżynierii i budownictwie, znajdziemy w tym momencie teksty, w których autorzy swoje badania osadzają głównie w ramach nauk społecznych czy też studiów organizacyjnych (Crawford i in., 2006).

Kluczowym krokiem dla konceptualizacji współczesnego rozumienia studiów nad projektami była praca J. Geraldi i J. Söderlunda (2018), którzy podjęli próbę opisu tej specjalności naukowej. Zanim jednak społeczność naukowa badaczy projektów (project scholars) ukuła termin project studies, podjęto szereg działań, które doprowadziły do dookreślenia i opisania założeń teoretycznych studiów nad projektami. Przede wszystkim tzw. „klasyczne zarządzanie projektami” uznane zostało za nie zawsze przystające do rzeczywistości organizacyjnej współczesnych firm i instytucji. W odpowiedzi na niedostatki klasycznego zarządzania projektami powstał kluczowy dla współczesnego naukowego rozumienia istoty projektów nurt Rethinking Project Management (RPM), na bazie którego krytycznej analizie poddano dotychczasowe założenia badań naukowych nad projektami. Obok RPM ważną rolę w definiowaniu obszaru naukowego badań nad projektami odgrywa nurt Making Projects Critical (MPC), skupiający badaczy wpisujących się w krytyczne studia nad projektami (Hodgson, Cicmil, 2008). Klasyczne zarządzanie projektami, RPM oraz MPC wyraźnie się od siebie różnią w swoich deklaracjach, ale podejść tych nie warto postrzegać jako dychotomicznych, a raczej dualistycznych, „łączących stare prawdy i nowe spojrzenia” (Svejvig, Andersen, 2015, s. 280; Jugdev i in., 2001).

Przywołani wyżej J. Geraldi i J. Söderlund (2018) zaproponowali w konsekwencji wprowadzenie pojęcia "project studies" jako sposobu rozumienia specjalności naukowej na obecnym etapie jej rozwoju, swoistego parasola, pod którym zebrać można wszystkie nurty i koncepcje, 
jakimi zajmują się badacze projektów. Wprowadzili oni dwie odrębne typologie, prezentujące typy studiów nad projektami oraz poziomy poznania $w$ ich ramach, następnie łącząc je i prezentując w przejrzysty sposób różnorodność dyscypliny. Zainspirowani teorią komunikacyjnego działania J. Habermasa (1981) J. Geraldi i J. Söderlund (2018, s. 60) wyróżnili trzy podstawowe typy studiów nad projektami: Typ 1, Typ 2 oraz Typ 3. W ramach pierwszego $\mathrm{z}$ nich badania skupiają się głównie na aspektach technicznych, przewidywaniu i kontroli, a także poszukiwaniu przyczynowych wyjaśnień zjawisk. Badania poruszają klasyczne i konwencjonalne tematy, wnosząc pewien wkład w rozwój dyscypliny. W ten typ wpisują się tzw. klasyczne studia nad projektami. Drugi typ jest głęboko zakorzeniony $\mathrm{w}$ idei zrozumienia natury i dynamiki systemów społecznych w bardziej ogólnym ujęciu. Doceniany jest rozwój modeli jako intelektualnych narzędzi do analizy społecznych aspektów świata projektów, a w konsekwencji przyczynia się do rozwoju teoretycznego $\mathrm{w}$ ramach ogólnej teorii organizacji i zarządzania, wychodząc poza teoretyzowanie jedynie na poziomie projektów. Drugi typ zazwyczaj podnosi krytykę typu pierwszego, jako zbyt racjonalistycznego, niepowiązanego $\mathrm{z}$ kontekstem społecznym. Wiele cech tego typu posiada nurt Rethinking Project Management. Trzeci typ dąży do realizacji interesów emancypacyjnych, zakładając, że krytyczna refleksja powinna zakończyć się celowymi zmianami w status quo. Badacze $\mathrm{w}$ ramach typu trzeciego często kwestionują ontologiczne, epistemologiczne czy też metodologiczne założenia studiów nad projektami. Idee tego typu realizuje w swoim programie badawczym m.in. Making Projects Critical.

Dzieląc studia nad projektami na trzy poziomy, tj. makro, mezo i mikro, J. Geraldi i J. Söderlund zwracają uwagę na różnorodność podejmowanych tematów badawczych. Ta typologia pokazuje wyraźnie ewolucję w myśleniu o przedmiocie badań w ramach dyscypliny i zdecydowanym odejściu od myślenia o pojedynczym projekcie jako jedynym przedmiocie refleksji naukowej. Na poziomie makro badania dotyczą m.in. portfeli projektów, społeczeństwa projektu, firm, zarządzania programami, strategii, zmian korporacyjnych, międzyprojektowego uczenia się. Poziom mezo to poziom badań nad projektami, problemami współpracy i koordynacji w ramach projektów, zarządzania czasem, kompetencjami, komunikacją i konfliktami w projektach itd., czyli klasycznymi zagadnieniami projektowymi. Na poziomie mikro badania dotyczą zaś m.in. ludzi w projektach, zespołów, aspektów psychologicznych, kariery, motywacji, zespołów wirtualnych. Łącząc te 2 typologie, J. Geraldi i J. Söderlund (2018, s. 63) otrzymali zestaw 9 współistniejących form, pokazujących jak różnorodną i bogatą dyscypliną stały się studia nad projektami.

Projektyzacji jako zjawiska nie można wpisać w żaden z tych poziomów i typów na wyłączność. Projektyzacja przenika bowiem różne poziomy analizy, a także badana jest $\mathrm{w}$ odniesieniu do bardzo różnorodnych obszarów ludzkiej aktywności, co przedstawione zostanie $\mathrm{w}$ dalszej części artykułu.

\section{Projektyzacja - definicje i poziomy badania zjawiska}

D rojektyzacja definiowana jest w literaturze na wiele różnych sposobów - zarówno jako zjawisko organizacyjne, jak i społeczne. Na różnych poziomach struktur społecznych przyczyny jej dynamicznego rozwoju różnią się - czasem jest to potrzeba uelastycznienia organizacji pracy poprzez wprowadzenie formy projektowej, czasem konieczność rozwiązania skomplikowanego problemu społecznego, do czego wykorzystuje się liczne projekty. Pierwotne jej rozumienie zaproponowane przez Ch. Midlera (1995) określało projektyzację jako proces transformacji organizacji poprzez projekty (a nie jedynie jako proces zwiększania liczby projektów w organizacji, co błędnie powielano w szeregu publikacji) (Aubry, Lenfle, 2012). Inni badacze definiują projektyzację jako racjonalizację, formalizację i proceduralizację działań projektowych (Maylor i in., 2006, s. 670; Dornisch, 2002, s. 311). Wraz z rozwojem badań zaczęto jednak dostrzegać szerszy, społeczny kontekst projektyzacji, rozumiejąc ją jako wielowymiarowe zjawisko o charakterze kulturowym i dyskursywnym (Packendorff, Lindgren, 2013). Projektyzacja bywa też rozumiana jako proces adaptacji struktur, języka, swoistych rytuałów i symboli projektowych. Przyjmując szeroką perspektywę, obejmującą nie tylko aspekty organizacyjne, ale i społeczne, można rozumieć też projektyzację jako „instytucjonalizację projektów w społeczeństwie” (Jacobsson, Jałocha, 2018).

Jak pokazuje przegląd literatury przedmiotu, w ramach którego M. Jacobsson i B. Jałocha (2018) poddali analizie ponad 100 tekstów naukowych podejmujących temat projektyzacji, zjawisko to stało się przedmiotem szeregu naukowych dociekań badaczy w ramach nauk o zarządzaniu, a także poza nimi. Jednocześnie należy zwrócić uwagę, że w podejmowanych badaniach rozpatrywano zagadnienie w odniesieniu do trzech głównych poziomów: indywidualnego (mikro), organizacyjnego (mezo) oraz społecznego (makro) (Kuura, 2011, s. 119; Jacobsson, Jałocha, 2018). Częściowo koresponduje to $\mathrm{z}$ poziomami studiów nad projektami, jakie zaproponowali J. Geraldi i J. Söderlund (2018). Główna różnica polega jednak na tym, że w przypadku studiów nad projektami przedmiotem badania jest zazwyczaj projekt, a w przypadku badań nad projektyzacją - projektyzująca się organizacja. Utożsamianie procesów projektyzacji z projektyzacją organizacyjną jest jednak mocno blokujące i nie pozwala na zrozumienie szerszego obrazu zagadnienia.

Wobec powyższego, bazując na dogłębnej analizie zjawiska, w artykule proponuje się rozszerzenie typologii poziomów badania zjawiska projektyzacji. Obowiązujący podział nie do końca może odzwierciedlać charakter występowania zjawiska - projektyzacja przenika bowiem różnorodne elementy i poziomy życia społecznego, prowadząc do „projektyzacji wszystkiego” (Jensen i in., 2016). Wraz z rozwojem badań nad projektyzacją można zauważyć, że zjawisko to jest zdecydowanie bardziej skomplikowane, niż pierwotnie zakładano, a jego badanie prowadzić można na większej liczbie wzajemnie ze sobą powiązanych poziomów (tab. 1). 
Tabela 1. Typologia poziomów badania projektyzacji²

\begin{tabular}{|l|l|}
\hline \multicolumn{1}{|c|}{$\begin{array}{c}\text { Poziom badania } \\
\text { projektyzacji }\end{array}$} & \multicolumn{1}{c|}{ Obszar badania } \\
\hline Meta & $\begin{array}{l}\text { Relacje i trendy transformujące } \\
\text { globalne struktury społeczne }\end{array}$ \\
\hline Mega & $\begin{array}{l}\text { Społeczeństwa, kraje, } \\
\text { ponadnarodowe organizacje }\end{array}$ \\
\hline Makro & Branże, sektory \\
\hline Mezo & Organizacje \\
\hline Mikro & Jednostki \\
\hline
\end{tabular}

Źródło: Jałocha, 2018

Najbardziej złożonym poziomem badania projektyzacji jest poziom meta. Na tym poziomie obserwować możemy relacje i trendy, które transformują globalne struktury społeczne. Można założyć, że przy powszechności trendów projektyzacyjnych są one możliwe do zaobserwowania na tym poziomie, ale w chwili obecnej brak jest szerszych badań podejmujących tę problematykę. Na poziomie mega obserwowane są zjawiska projektyzowania się całych społeczeństw (Jensen i in., 2016; Lundin i in., 2015), krajów i regionów (Fred, 2018) czy też ponadnarodowych organizacji, takich jak Unia Europejska, ONZ czy Kościół katolicki (Büttner, Leopold, 2016; Godenhjelm i in., 2015). Poziom makro odpowiada poziomowi sektorów oraz branż. Badania opisujące procesy projektyzacyjne na tym poziomie często odnoszą się do sektora publicznego (Hodgson i in., 2019). Poziom mezo dotyczy głównie procesów restrukturyzacji organizacji i zwiększenia przewagi projektów w organizacjach. Przedmiotem zainteresowania są tu więc m.in. konsekwencje procesu projektyzacji dla organizacji, zmiany w strukturze governance oraz instytucjonalizacja operacji projektowych (Jacobsson, Jałocha, 2018). Przykłady badań odnoszących się do tego poziomu podają m.in.: I. Bergman i in. (2013), K. Bredin (2006), M. Fred, P. Hall, (2017), T. Wenell i in.(2017).

$\mathrm{Na}$ poziomie mikro badania dotykają wpływu procesu projektyzacji na jednostki, czyli na pojedynczych ludzi. Nie są to tylko osoby formalnie włączone w prace projektowe (kierownicy projektów, członkowie zespołów) - mogą to być też wszystkie osoby, na których życie prywatne i zawodowe wpływają zasady projektowe. Wśród poruszanych tematów znajdziemy m.in. zmiany w relacjach pracy oraz życiu prywatnym poprzez zwiększony udział w pracach projektowych. Badania na tym poziomie odnoszą się więc głównie do procesów osobistej projektyzacji dziejącej się na tle projektyzującego się społeczeństwa (Cicmil i in., 2016; Szreder, 2015; Ekstedt, 2009).

Należy zauważyć, że niejednokrotnie trudno jest zrozumieć procesy projektyzacji w odniesieniu do jednego poziomu. Zazwyczaj procesy projektyzacyjne w sposób kaskadowy przenikają poszczególne poziomy życia społecznego, wpływając na zmiany na różnych poziomach: w sprojektyzowanych organizacjach łatwiej o przenoszenie praktyk projektowych na życie prywatne jednostek
(Hodgson i in., 2019; Jałocha, Ćwikła, 2019). Oznaczać to może, że dotychczasowy trend badania procesów projektyzacyjnych, który zakładał skupianie się na jednym poziomie społecznym, miał charakter ograniczający dla pełnego poznania tego zjawiska.

\section{Obszary podejmowania badań nad projektyzacją}

W swoich badanaich Ch. Midler (1995) zainicjował dyskusję naukową nad zjawiskiem projektyzacji. Autor skupił się na jednym poziomie badania tego zjawiska, poziomie mezo, badając firmę z branży automotive. Podobnie było w przypadku kolejnych badań naukowych nad projektyzacją - ich obszar przedmiotowy stanowiły często pojedyncze organizacje. Jednak, jak wskazują badania M. Jacobssona i B. Jałochy (2018), przez ostatnie 25 lat badacze projektyzacji znacząco rozszerzyli swoje zainteresowania również na nowe obszary. Widoczny jest ponadto wyraźny trend, w którym ma miejsce kumulacja badań nad projektyzacją na grupie wybranych obszarów, a wśród nich, oprócz wspomnianego automotive, szczególnie wyróżniają się: sektor publiczny, pozarządowy, nauka, kultura oraz służba zdrowia.

Projektyzacja sektora publicznego oraz polityk publicznych jest jednym z najczęściej poruszanych zagadnień w zakresie obszarów projektyzacji. W jednym z pierwszych tekstów dotyczących zagadnienia projektyzacji sektora publicznego S. Sjoblom (2006, s. 9) zwrócił uwagę na fakt, że zmiany następujące w sektorze publicznym mogą zmierzać w kierunku "projectified public sector". Projektyzacja sektora publicznego badana jest często na poziomie organizacji publicznych szczebla lokalnego (Waring, Thomas, 2010; Jałocha 2012; Fred, 2014; Fred, Hall, 2017). Jednocześnie ważnym wątkiem jest kwestia projektyzujących się polityk publicznych i konsekwencji, jakie dla ich programowania i implementacji ma wybór formy projektowej (Jensen i in., 2017). Analizie poddawane są różnorodne polityki publiczne - np. polityki uczenia się przez całe życie (Jałocha, Prawelska-Skrzypek, 2017), kulturalne (Jałocha, Ćwikła, 2019), dotyczące procesów migracji (Abrahamsson, Agevall, 2010). Istotnym wątkiem, stanowiącym bardzo często tło dla rozważań nad wpływem projektyzacji na sektor publiczny jest projektyzacja Unii Europejskiej. Unia Europejska wskazywana jest jako główny katalizator procesów projektyzacji w Europie, poprzez wykorzystanie projektów we wdrażaniu lokalnych polityk publicznych (Godenhjelm i in., 2015, Jałocha, 2012, Büttner, Leopold, 2016). Dostrzec można budowę środowiska badaczy projektyzacji sektora publicznego, co następuje poprzez organizowane cykliczne spotkania, w tym w ramach większych konferencji, takich jak IRSPM. W 2019 roku ukazała się również pierwsza kompleksowa i spójna publikacja naukowa dotycząca wielu obszarów projektyzacji sektora publicznego, wydana przez wydawnictwo Routledge (Hodgson i in., 2019).

Przedmiotem badań w ramach studiów nad projektami zaczyna być także silna projektyzacja sektora pozarządowego. Badacze zauważają, że projektowa forma organizacji 
pracy w sektorze non profit ma wpływ na wiele obszarów społeczeństwa ze względu na bardzo różnorodny przedmiot działań tych organizacji (Sohmen, 2001). Projekty są swoistą "naturalną" formą realizacji zadań w sektorze pozarządowym, co wynika m.in. $z$ tego, że organizacje te w dużej mierze zdobywają środki na działania w formie grantów (Jałocha, Bogacz-Wojtanowska, 2016). Zwraca się również uwagę na to, że praca projektowa wpływa na prekaryzację pracy w trzecim sektorze (Szreder, 2015).

Projektyzacja coraz częściej analizowana jest również w obszarze nauki. Projektyzacja nauki odbywa się poprzez system aplikacji o granty, praktyki ich codziennego zarządzania, zasady raportowania, a także kształcenie naukowców na specjalistycznych kursach z zarządzania projektami (Fowler i in., 2015; Baur i in., 2018). Projekty zmieniają nie tylko system realizacji badań, ale wpływają też na indywidualnych naukowców poprzez ciągłe zaangażowanie ich w zdobywanie i realizację kolejnych projektów badawczych (Ylijoki, 2016).

Wśród innych obszarów, które wzbudzają rosnące zainteresowanie badaczy, jest m.in. kultura (Ćwikła, Jałocha, 2015; Szreder, 2015; Ćwikła, 2016), służba zdrowia (Meinert, Whyte, 2014) oraz edukacja (Kalff, 2017). Zdarzają się, choć bardzo rzadko, badania o charakterze interdyscyplinarnym, gdy projektyzacja rozpatrywana jest jako zjawisko wielowymiarowe i przenikające szereg różnych obszarów (np. Jensen i in., 2016; Lundin i in., 2015).

Jak pokazuje powyższy przegląd literatury, wzrasta różnorodność obszarów, w jakich podejmowane są badania nad projektyzacją. Procesy projektyzacyjne nie są już poddawane analizie jedynie w tradycyjnych, "projektowych" branżach i sektorach (takich jak budownictwo czy IT). Potwierdza to, że badania nad tym zjawiskiem zaczynają przekraczać granice dyscyplin naukowych.

\section{Podsumowanie}

D rojektyzacja stała się jednym z zagadnień coraz częściej poddawanym analizie $\mathrm{w}$ ramach studiów nad projektami. Świadczy o tym zarówno wzrost liczby publikacji w uznanych magazynach naukowych, jak i budowa środowiska badaczy wokół konferencji i paneli konferencyjnych poświęconych temu zagadnieniu.

Celem tego opracowania było udzielenie odpowiedzi na postawione pytania badawcze (PB 1: W jaki sposób definiowana jest projektyzacja? oraz PB 2: W odniesieniu do jakich poziomów i w ramach jakich obszarów badane jest zjawisko projektyzacji?). Odnosząc się do pierwszego z pytań badawczych, można zauważyć, że po 25 latach od publikacji tekstów naukowych na temat tego zagadnienia autorstwa Ch. Midlera, pojęcie to definiowane jest w znacząco szerszy, holistyczny sposób, jako rodzaj fenomenu przenikającego różne struktury społeczne. Zagadnienie, które jako pierwsi eksplorowali badacze zarządzania, podejmowane jest aktualnie przez wielu naukowców $\mathrm{z}$ innych dziedzin nauki. Projektyzacja jest jednym z przedmiotów badania $\mathrm{w}$ ramach studiów nad projektami. Nie daje się ona jednak łatwo ująć w ramy klasycznego podziału dziedzin i dyscyplin nauki. Coraz częściej jest przedmiotem badań multidyscyplinarnych, realizowanych przez badaczy z nurtu zarządzania, jak i innych nauk, np. socjologii (Rapior, 2017) czy też sztuki (Szreder, 2016). $\mathrm{Na}$ bazie dokonanej analizy literatury przedmiotu proponuje się więc szeroką definicję tego zjawiska, definiującą projektyzację jako proces instytucjonalizacji projektów na wszystkich poziomach struktur społecznych poprzez adaptację metod, języka i praktyk projektowych.

$\mathrm{W}$ odpowiedzi na drugie $\mathrm{z}$ postawionych pytań badawczych $\mathrm{w}$ artykule opisano dotychczas wskazywane $\mathrm{w}$ literaturze poziomy badania projektyzacji i przedstawiono typologię, rozszerzającą dotychczasowe podejście o poziomy mega i meta, zwracające uwagę na skomplikowany i kompleksowy charakter analizowanego zagadnienia. Ponadto analiza literatury wykazała, że badanie projektyzacji nie ogranicza się jedynie do analizy jej wpływu i znaczenia w obszarze organizacji biznesowych. Powyższa analiza literatury pokazuje, że badania nad projektyzacją realizowane są w nieco innych obszarach niż klasyczne badania w ramach studiów nad projektami. Jak zauważają M. Jacobsson i J. Jałocha (2018), zjawisko to badane jest niezwykle często poza obszarami, gdzie projekty stanowią organizacyjne modus operandi, a projekty są częścią „organizacyjnego DNA”.

Tabela 2. Definicje, poziomy i gtówne obszary badania zjawiska projektyzacji

\begin{tabular}{|c|c|c|}
\hline \multicolumn{3}{|c|}{ Projektyzacja } \\
\hline Definicje & Poziomy badania & Główne obszary badań \\
\hline $\begin{array}{l}\text { - proces transformacji organizacji poprzez } \\
\text { projekty (Aubry, Lenfle, 2012) } \\
\text { racjonalizacja, formalizacja } \\
\text { i proceduralizacja działań projektowych } \\
\text { (Maylor i in., 2006, s. 670; Dornisch, 2002, } \\
\text { s. 311) } \\
\text { - wielowymiarowe zjawisko o charakterze } \\
\text { kulturowym i dyskursywnym (Packendorff, } \\
\text { Lindgren, 2013) } \\
\text { - instytucjonalizacja projektów } \\
\text { w społeczeństwie (Jacobsson, Jałocha, } \\
\text { 2018) }\end{array}$ & $\begin{array}{l}\text { - Meta (Relacje i trendy transformujące } \\
\text { globalne struktury społeczne) } \\
\text { - Mega (Społeczeństwa, kraje, } \\
\text { ponadnarodowe organizacje) } \\
\text { - Makro (Branże, sektory) } \\
\text { - Mezo (Organizacje) } \\
\text { - Mikro (Jednostki) }\end{array}$ & $\begin{array}{l}\text { - Biznes } \\
\text { - Sektor publiczny } \\
\text { - Ochrona zdrowia } \\
\text { - Edukacja i badania naukowe } \\
\text { - Programy pomocowe } \\
\text { - Unia Europejska } \\
\text { - Sektor pozarządowy }\end{array}$ \\
\hline
\end{tabular}


Podsumowanie uzyskanych dzięki badaniu informacji zaprezentowano w tabeli 2.

Analiza pokazała też pewne niedobory charakteryzujące badania nad projektyzacją, które mogą stanowić lukę badawczą i być inspiracją do kolejnych badań. Istnieje bardzo mało doniesień naukowych, które opisywałyby rozwój procesów projektyzacyjnych w takich branżach, jak np. budownictwo, IT, przemysł. Poza kilkoma wyjątkami (Schoper i in., 2018, Wald i in., 2015) nie ma też szerszych badań przekrojowych i porównawczych dotyczących tego zjawiska w różnych branżach oraz różnych krajach, a także pogłębionych badań ilościowych. Ponadto słabością badań nad projektyzacją jest to, że duża część artykułów naukowych nie jest osadzona w obszarze konkretnych teorii naukowych (Jacobsson, Jałocha, 2018). Jest to zapewne przejaw tego, że badania nad projektyzacją wciąż się rozwijają i dlatego przeważają artykuły o charakterze koncepcyjnym oraz raportującym badania, a nie teoriotwórcze.

Poprzez zdefiniowanie pojęcia projektyzacji, wskazanie możliwych poziomów jej badania, a także obszarów, jakimi zajmują się jej badacze, nakreślony został holistyczny obraz zjawiska na tle studiów nad projektami. Praca ta wpisuje się w podejmowany przez naukowców badających projektyzację proces budowy agendy badawczej, w celu rozszerzenia pola badań nad projektyzacją poza jej dotychczasowe podstawy.

Praca posiada pewne ograniczenia. Po pierwsze bazuje ona na tradycyjnym przeglądzie literatury, którego kontynuacją mógłby się stać systematyczny przegląd literatury, obejmujący swoim zakresem większą liczbę baz danych (np. Scopus, EBSCO). Zasadne byłoby też zastosowanie technik uzupełniających w procesie doboru literatury do analizy, np. techniki kuli śnieżnej, polegającej na włączaniu tekstów wskazywanych $\mathrm{w}$ analizowanych opracowaniach. Po drugie w pracy skupiono się na wąskim wycinku analizy fenomenu projektyzacji - definicjach, obszarach i poziomach badania. Istotne wydaje się podjęcie rozszerzonego badania, w którym poddano by analizie również aspekty metodologiczne prac badawczych z zakresu projektyzacji. Dzięki temu możliwe będzie uzyskanie jeszcze szerszego obrazu badanego zjawiska.

\section{dr Beata Jałocha \\ Uniwersytet Jagielloński w Krakowie \\ Wydział Zarządzanie i Komunikacji Społecznej \\ ORCID: 0000-0003-2297-5637 \\ e-mail: beata.jalocha@uj.edu.pl}

\section{Przypisy}

1) Praca powstała $w$ wyniku realizacji projektu badawczego o numerze 2016/23/D/HS4/01810 finansowanego ze środków Narodowego Centrum Nauki.

2) Jałocha B., The Story of Projectfication - Past, Present and an Outlook on its Future Development, prezentacja konferencyjna, 6th IPMA Research Conference: Project Management and its Impact on Societies, Rio de Janeiro, Brazil, 3-4 September 2018.

\section{Bibliografia}

[1] Abrahamsson A., Agevall L. (2010), Immigrants Caught in the Crossfire of Projectification of the Swedish Public Sector: Short-term Solutions to Long-term Problems, "Diversity in Health and Care", Vol. 7, pp. 201-209.

[2] Alvesson M., Gabriel Y., Paulsen R. (2017), Return to Meaning. A Social Science with Something to Say, Oxford University Press, Oxford.

[3] Amara N., Landry R. (2012), Counting Citations in the Field of Business and Management: Why Use Google Scholar Rather than the Web of Science, „Scientometrics”, Vol. 93, No. 3, pp. 553-581.

[4] Aubry M., Lenfle S. (2012), Projectification: Midler's Footprint in the Project Management Field, „International Journal of Managing Projects in Business", Vol. 5, pp. 680-694.

[5] Baur N., Besio C., Norkus M. (2018), Projectification of Science as an Organizational Innovation, [in:] W. Rammert, A. Windeler, H. Knoblauch, M. Hutter (eds.), Innovation Society Today, Springer VS, Wiesbaden, pp. 341-370.

[6] Bergman I., Gunnarson S., Räisänen C. (2013), Decoupling and Standardization in the Projectification of a Company, „International Journal of Managing Projects in Business", Vol. 6, No. 1, pp. 106-128.

[7] Bredin K. (2006), Human Resources Management in Project-Based Organisations: Challenges and Changes, praca doktorska, Linköpings Universitet.

[8] Büttner S., Leopold L. (2016), A 'New Spirit' of Public Poli$c y$ ? The Project World of EU Funding, „European Journal of Cultural and Political Sociology", Vol. 3, No. 1, pp. 41-71.

[9] Cicmil S., Lindgren M., Packendorff J. (2016), The Project Management Discourse and its Consequences: On Vulnerability and Unsustainability in Project-based Work, „New Technology, Work and Employment", Vol. 31, No. 1, pp. 58-76.

[10] Crawford L., Pollack J., England D. (2006), Uncovering the Trends in Project Management: Journal Emphases over the Last 10 Years, „International Journal of Project Management", Vol. 24, No. 2, pp. 175-184.

[11] Ćwikła M. (2016), Projekt to jest projekt: Specyfika zarzadzania projektami kulturalnymi na przykładzie koprodukcji teatralnych, Wydawnictwo Attyka, Kraków.

[12] Ćwikła M., Jałocha B. (2015), Unspread Wing: Why Cultural Projects don't Provide Refreshing Ideas for Project Management although They Could? „International Journal of Managing Projects in Business", Vol. 8, No. 4, pp. 626-648.

[13] Dornisch D. (2002), The Evolution of Post-socialist Projects: Trajectory Shift and Transitional Capacity in a Polish Region, „Regional Studies”, Vol. 36, No. 3, pp. 307-321.

[14] Ekstedt E. (2009), A New Division of Labour: The „Projectification" of Working and Industrial Life, [in:] M.-A. Moreau, S. Negrelli, P. Pochet (eds.), Building Anticipation of Restructuring in Europe, Presses Interuniversitaires Europeennes, Brussels, pp. 31-53.

[15] Evaristo R., van Fenema P. C. (1999), A Typology of Project Management: Emergence and Evolution of New Forms, „International Journal of Project Management", Vol. 17, No. 5, pp. 275-281.

[16] Fowler N., Lindahl, M., Sköld D. (2015), The Projectification of University Research, „International Journal of Managing Projects in Business", Vol. 8, No. 1, pp. 9-32. 
[17] Fred M. (2014), Porous organizing. Making sense of projectification in Swedish Municipalities, Paper presented at the 7th Making Project Critical Workshop, Stockholm, Sweden.

[18] Fred M. (2018), Projectification - The Trojan Horse of Local Government, praca doktorska, Lund University, Malmö.

[19] Fred M., Hall P. (2017), A Projectified Public Administration. How Projects in Swedish Local Governments Become Instruments for Political and Managerial Concerns, „Statsvetenskaplig Tidskrift", Vol. 119, No. 1, pp. 185-205.

[20] Gehanno J.F., Rollin L., Darmoni S. (2013), Is the Coverage of Google Scholar Enough to Be Used Alone for Systematic Reviews, „BMC Medical Informatics and Decision Making”, Vol. 13, No. 1, pp. 1-5.

[21] Geraldi J., Söderlund J. (2018), Project Studies: What It Is, Where It Is Going, „International Journal of Project Management", Vol. 36, No. 1, pp. 55-70.

[22] Godenhjelm S., Lundin R.A., Sjöblom S. (2015), Projectification in the Public Sector - The Case of the European Union, "International Journal of Managing Projects in Business", Vol. 8, No. 2, pp. 324-348.

[23] Habermas J. (1981), The Theory of Communicative Action, Volume 1: Reason and the Rationalization of Society, Polity.

[24] Hirsch P.M., Levin D.Z. (1999), Umbrella Advocates versus Validity Police: A Life-cycle Model, „Organization Science”, Vol. 10, No. 2, pp. 199-212.

[25] Hodgson D., Cicmil S. (2008), The other Side of Projects: The Case for Critical Project Studies, „International Journal of Managing Projects in Business", Vol. 1, No. 1, pp. 142-152.

[26] Hodgson D., Fred M., Bailey S., Hall P. (eds.), (2019), The Projectification of the Public Sector, Routledge, New York.

[27] Jacobsson M., Jałocha B. (2018), A Literature Review on Projectification: Trends, Emerging Ideas and Avenues for Future Research, Paper presented at the the 14th International Research Network on Organizing by Projects (IRNOP) Conference, Melbourne, Australia.

[28] Jałocha B. (2012), Projectification of the European Union and its Implications for Public Labour Organizations, "Journal of Project, Program \& Portfolio Management", Vol. 3, No. 2, pp. 1-16.

[29] Jałocha B., Bogacz-Wojtanowska E. (2016), The Bright Side of Social Economy Sector's Projectification: A Study of Successful Social Enterprises, „Project Management Research and Practice", Vol. 3, pp. 5043-5063.

[30] Jałocha B., Ćwikła M. (2019), Observing the Process of Culture Projectification and its Agents. A Case Study of Kraków, [in:] D. Hodgson, M. Fred, S. Bailey, P. Hall (eds.), The Projectification of the Public Sector, Routledge, New York, London, pp. 209-228.

[31] Jałocha B., Prawelska-Skrzypek G. (2017), Public Policies and Projectification Processes, [in:] B. Jałocha, R. Gansiniec-Lenart, E. Bogacz-Wojtanowska, G. Prawelska-Skrzypek (eds.), The Complex Identity of Public Management: Aims, Attitudes, Approaches, Instytut Spraw Publicznych, Kraków, pp. 135-147.

[32] Jensen A., Thuesen C., Geraldi J. (2016), The Projectification of Everything: Projects as a Human Condition, „Project Management Journal", Vol. 47, No. 3, pp. 21-34.

[33] Jensen C., Johansson S., Löfström M. (2017), Policy Implementation in the Era of Accelerating Projectification: Synthesizing Matland's Conflict-ambiguity Model and Research on
Temporary Organizations, „Public Policy and Administration", pp. 1-19.

[34] Jesson J., Matheson L., Lacey F.M. (2011), Doing Your Literature Review. Traditional and Systematic Techniques, SAGE, London.

[35] Jugdev K., Thomas J., Delisle C.L. (2001), Rethinking Project Management: Old Truths and New Insights, „Project Management Journal", Vol. 7, No. 1, pp. 36-43.

[36] Kalff Y. (2017), The Knowledge Worker and the Projectified Self: Domesticating and Disciplining Creativity, „Work Organisation, Labour \& Globalisation", Vol. 11, No. 1, pp. 10-27.

[37] Kuura A. (2011), Policies for Projectififacion-support, Avoid or Let It Be, „Discussions on Estonian Economic Policy”, January.

[38] Lundin R.A., Arvidsson N., Brady T., Ekstedt E., Midler Ch., Sydow J. (2015), Managing and Working in Project Society, Institutional Challanges of Temporary Organizations, Cambridge University Press, Cambridge.

[39] Maylor H., Brady T., Cooke-Davie T., Hodgson D. (2006), From Projectification to Programmification, „International Journal of Project Management", Vol. 24, No. 8, pp. 663-674.

[40] Meinert L., Whyte S.R. (2014), Epidemic Projectification: AIDS Responses in Uganda as Event and Process, „The Cambridge Journal of Anthropology", Vol. 32, No. 1, pp. 77-94.

[41] Midler Ch. (1995), Projectification of the Firm - The Renault Case, „Scandinavian Journal of Management”, Vol. 11, No. 4, pp. 363-375.

[42] Morris P.W.G. (1994), The Management of Projects, Thomas Telford, London.

[43] Packendorff J. (1995), Inquiring into the Temporary Organization: New Directions for Project Management Research, „Scandinavian Journal of Management", Vol. 11, No. 4, pp. 319-333.

[44] Packendorff J., Lindgren M. (2013), Projectification and its Conseqeunces - Narow and Broad Conceptualization, „SAJEMS", Vol. 17, pp. 7-21.

[45] Pollack J., Adler D. (2015), Emergent Trends and Passing Fads in Project Management Research: A Scientometric Analysis of Changes in the Field, „International Journal of Project Management", Vol. 33, No. 1, pp. 236-248.

[46] Rapior W. (2017), Życie w projekcie. Projekt jako narzędzie przeksztatcania świata i rama instytucjonalna rzeczywistości społecznej, praca doktorska, Uniwersytet im. Adama Mickiewicza w Poznaniu, Poznań.

[47] Schoper Y.-G., Wald A., Ingason H.T., Fridgeirsson T.V. (2018), Projectification in Western Economies: A Comparative Study of Germany, Norway and Iceland, „International Journal of Project Management", Vol. 36, No. 1, pp. 71-82.

[48] Sjöblom S. (2006), Introduction: Towards a Projectified Public Sector: Project Profileration as a Phenomenon, [in:] S. Sjöblom (ed.), Project Proliferation and Governance: The Case of Finland Helsinki: Research Institute, Swedish School of Social Science University of Helsinki, pp. 9-31.

[49] Sohmen V. (2001), Projectification of Society: A Look at the Blind Side, Paper presented at the Project Research Conference VIII, Vienna, Austria.

[50] Svejvig P., Andersen P. (2015), Rethinking Project Management: A Structured Literature Review with a Critical Look at the Brave new World, „International Journal of Project Management", Vol. 33, No. 2, pp. 278-290.

[51] Szreder K. (2015), How to Radicalize a Mouse? Notes on Radical Opportunism, [in:] N. Dockx, P. Gielen (eds.), Mobile 
Autonomy. Exercises in Artists' Self-Organization, Meatahaven, Valiz, pp. 183-205.

[52] Szreder K. (2016), ABC projektariatu. O nędzy projektowego życia, Fundacja Bęc Zmiana, Warszawa.

[53] Trocki M. (2005), Tożsamość nauk o zarządzaniu, „Przegląd Organizacji”, Nr 1, s. 7-11.

[54] Trocki M. (2019), Podejścia badawcze w zarządzaniu projektami - geneza i ewolucja, „Przegląd Organizacji”, Nr 3, s. 3-9.

[55] Trocki M., Bukłaha E. (red.), (2016), Zarzadzanie projektami - wyzwania i wyniki badań, Oficyna Wydawnicza Szkoła Główna Handlowa w Warszawie, Warszawa.

[56] Wald A., Spanuth T., Schneider C., Schoper Y. (2015), Towards a Measurement of "Projectification” - A Study on the Share of Project Work in the German Economy, [in:] A. Wald, R. Wagner, C. Schneider, M. Gschwendtner (eds.), Advanced Project Management, Flexibility and Innovative Capacity, GPM Deutsche Gesellschaft für Projektmanagement e.V., Nuremberg.

[57] Waring T., Thomas P. (2010), The Insidious Growth of Societal Projectification: Emancipatory Research with Public Sector Staff in the North of England, Paper presented at the 5th Making Projects Critical Workshop, Bristol, UK.

[58] Wenell T., Ekstedt E., Lundin R.A. (2017), Managing and Working in Project Society - On the Road to Project Society - A Swedish Story, „PM World Journal”, Vol. 6, No. 1, pp. 1-6.
[59] Ylijoki O.-H. (2016), Projectification and Conflicting Temporalities in Academic Knowledge Production, "Theory of Science", Vol. XXXVIII, No. 1, pp. 7-26.

\section{Projectification as a Subject of Research within the Project Studies}

\section{Summary}

The purpose of this article is to discuss the phenomenon of projectification as a subject of research within the project studies. The article presents a description of the evolution of research on projects and the main assumptions of project studies. In addition, the concept of projectification has been defined, and the main areas of research on this phenomenon have been analysed. A new typology has been proposed, extending the existing levels of projectification research to include mega and meta levels, paying attention to the complex and comprehensive nature of the analysed issue.

\section{Keywords}

projectification, project studies, project management 